\title{
MEANING AND FUNCTION OF ANCIENT MANUSCRIPTS FOR THE CULTURE AND NATIONAL DEVELOPMENT THROUGH TEACHING HISTORY
}

\author{
Ufi Saraswati ${ }^{1}$
}

\begin{abstract}
The Indonesian people still keep old manuscripts in considerable amounts. The distribution of ancient manuscripts is found in almost all regions of Indonesian archipelago, although the amount of ancient manuscripts in each region is not same. The old manuscript can also be expressed as a document of a nation, because the document defined as an article containing crucial information. Today, teaching history using an ancient manuscript still rarely carried out by the teachers. However, it needs an attempt to understand the ancient texts that all information about the past delivered to the present and the future generation. Teaching history that relies on scarce resources has brought new challenges for teachers. In this country, the history science has become one of the compulsory subjects in the curriculum, since elementary school there is a question, has history teaching has run well? In fact, teaching history in schools is more than a transfer of teachers' knowledge to students in the classroom through the one-way communication. Pupil just become passive objects that have an obligation to memorize the teacher's notes in order to answer the questions that will be tested. This kind of teaching history method has made history as a boring lesson. As for to make history teaching successful, the method used should be construct "historical memory" accompanied by "emotional memories". Study of ancient texts in teaching history can be regarded as one of the methods that can lead to "emotional memories". After students are given the facts of history to construct "historical memory" in the classroom, emotional memory can be explored by studying the ancient texts. Several alternative methods in relation to the modification of the teaching of history need to be developed. One method that researcher through think could be applied is the utilization of the ancient manuscript to the teaching of history, particularly for the development of Culture and National Character.
\end{abstract}

Key words: Meaning and Function, manuscripts, Culture and National Character Development, Teaching history

\section{Introduction}

A nation's history can be traced from the study or research of authentic data sources. The data sources for teaching history rooted in the written and unwritten sources.
Unwritten sources including the building or ruins of a building somewhere that usually a fairly wide area, such as In Indonesia found relics of the Majapahit Empire in the region of East Java as the unwritten source. Meanwhile, the written sources include the

\footnotetext{
${ }^{1}$ Ufi Saraswati, lecturer of in History Department in State University of Semarang (Unnes). For academic interest, the author can be contacted through the office address: Gedung H Kampus Sekaran, Gunungpati, Semarang, 50229, Central Jawa, and email address: ufisaraswati@gmail.com.
} 
inscription, Charter, documents, inscription on the tombstone, especially manuscripts and ancient texts.

Unwritten or written sources as the data source for the teaching of history often provide important information. The important information is usually studied about social and cultural conditions within a certain time. When you do a comparison between the written and unwritten source, the written source will be more capable to use in historical and cultural teaching. In the written documents can be studied in a more tangible and careful of the nation's way of thinking.

The contents of the text or the written document often also provide information on thenation'sculturalaspectsofthecommunity. The information can be delivered from the ancient manuscripts includes the fields of philosophy, religious life, beliefs, technical issues such as residential development, land acquisition fields, teaching various types of expertise, and skills, as well as other things related to the purposes of the relevant life of the nation as a whole.

Today, government has not been paying attention the rescue the ancient manuscripts from the destruction. Hundreds of ancient manuscrift that are very valuable in terms of historical sources is considered owned by some people and stored in a damaged condition. It cannot be denied that the manuscript made from materials that easily weathered. In the UK our manuscript are logged carefully in a catalog arrange by $\mathrm{MC}$ Ricklefs and P. Voorhoeve. According to the catalog, our script have been living in Britain since the early 17th century, perhaps even earlier.

The texts were written in various languages such as Aceh, Bali, Batak, Bugis,
Javanese (ancient), Kalimantan, Lampung, Madura, Makasar, Malay , Minangkabau, Nias, Rejang, Sangir, Sasak, Sundanese (ancient), and Sulawesi (beside Bugis and Makassar). There more than 1,200. Everything is stored neatly in the 20 libraries and museums in several citties are in the UK. Most entire scrift collections are in the British Library and the School of Oriental and African Studies, where in places that archaeologists, historians, and philologists from all over the world, including Indonesia, often are doing some book research.

According to Annabel Teh Gallop, a staff of The British Library, during a visit to Jakarta in the 1990s, where she worked are keep many kind of saga, poetry, guidance, letters, until evidence of a trade transaction of the 15th century period. The materials were often used by Western and Indonesian teachers. According to Annabel because it stored neatly well-preserved, the manuscript role was much greater than the Indonesian National Library which is also collected many ancient manuscripts.

Many of the Indonesian manuscript stored in the Netherlands, because the Dutch as a colonialist really concern to ancient texts written by Indonesian. The Dutch Government, at that time, used the manuscript to know the customs and culture of Indonesian people, even the historical journeyofIndonesianpeoplebeforetheycome in the 16th century. The texts are stored in libraries and museums, such as Amsterdam, Leiden, Delft, and Rotterdam. Unlike the British, most of Indonesian manuscripts in the Netherlands are "masterpiece", it is understandable because the Dutch dominate our country longer than England.

Among the existing script, there is a very well-known one named 'Nagarakretagama'. The manuscript has been returned to 
Indonesia in 1970 s by Queen Juliana to the President Suharto, however it is unfortunate that the content of the manuscript have been studied by the Dutch scholars so we just received the "dreg " that are almost useless anymore. It is estimated that up to now there are still many Indonesian manuscripts owned by around 30 countries. Their knowledge of the ways a treating the manuscript is better. To prevent the manuscript getting ruined, they copied ancient manuscriptsin microfilm. The preservation of ancient manuscripts in this way of course have a positive impact for the users, not just practical but in the form of microfilm the manuscript are better protected from damage.

Ironically, in our own country a treatment was never carried out due to lack of human resources, technology, and funding. Thanks to the help of some outer country, a number of ancient manuscripts ever created for microfilming. As for example, Javanese manuscripts belongs to the Sultan's Palace addressed by D . Jennifer Lindsay from Australia. While the Bali's papyrus manuscripts computerized and sponsored by giant corporate, IBM. In 1989 the British Government presented Sri Sultan Hamengku Buwono X hundreds of microfilm of all Javas' script that is stored in the UK. This is because some of Javanese script comes from the region of Yogyakarta. In 1991 the National Library received a prize of recording microfilm manuscripts written in a variety of Indonesian regional languages from the British government, as their concern to the Indonesian cultural heritage. It would have been very embarrassing if our nation concern against his ancient texts not as high as their appreciation.

\section{The Meaning and Function of Manuscript}

Manuscript in Dutch called handscript. Manuscript is an Original handwritten at least 50 years old, and has significance for civilization, history, culture and science. In Indonesia there are three kind of manuscript, which are: 1) Islamic manuscripts, written in arabic manuscripts, 2) Jawi manuscripts, written in arabic script but use Malay language, to suit the Malay accent was given a few extra phoneme, and 3) Pegon manuscript, that is a script written with the Arabic but uses local languages such as Javanese, Sundanese, Bugis, Buton, Banjar, Aceh and others.

As a relic, themanuscriptis ableto provide the information on various aspects of the past community as a political, economy, social, cultural, traditional medicine, the veil of the earthquake or natural phenomena, human physic, and so on. Preliminary information relating to those things can be found in the content of the manuscript to be learned by everyone. The texts are important, both academically and socio-cultural. The script is the identity, the pride and a valuable cultural heritage. In socio-cultural, the manuscript contains values that are still relevant to the present life, so it becomes our responsibility to uncover the 'pearls' contained within. Ancient manuscripts not only use as cultural documentation but also used as teaching object to take the values and the content. These values are needed to connect virtues that existed in the past to apply today.

Another definition of the script is paper made directly by hand, not through mechanical stationery, such as typewriters, printing machine, and computer. The Script writing is done, when there was 
not mechanical stationery. In Sunda area, including Banten, the manuscript was made since Sunda Kingdom (late of 7 th century until the late of 16th century) and ended towards the end of the 2oth century.

The manuscript was born closely linked to the emergence of read-write skills in the community. Write and read skills closely related to the appearance of characters as symbols issued at the human voice. The human voice is called oral language which is a tool of social communication among them. In Tatar Sunda the proof of script for the first time known through inscriptions, namely the inscription on the stone. The inscription is thought come from about the middle of the $5^{\text {th }}$ century, when the Kingdom Tarumanagara still standing (late 4th century until the end of the 7 th century). The seven pieces inscription was carved with Pallawa script and Sanskrit language.

The existence of the ancient manuscript as one of the cultural heritage, provide a record evidence of our culture in the past. These manuscrift are kind of pictures of the era that explains various things about that time, so its value is very important and strategic. Therefore we need concrete steps to rescue and conserve the manuscripts. The manuscript became one of the cultural documentation that not only contains the values of tradition, but also the codex which is the media to observe and study other cultures (including our culture).

In some manuscripts such as Riau Malay laws , like the Law of Kedah, Melaka Act, Act of Johor and Melaka Sea Act, a lot of text explaining about the traditional life of the Malays as a whole. The manuscript collection provides explain an overview of how the form of the Malay community life in the past, which is then granted a judgment and interpretation. As expressed by Jelani Harun, in the "Malay Customary Law Manuscript Studies in London". Foreign teachers from London applied the law in the interests of London society themself. They made Malay laws manuscript as a means to understand the customs and culture of the Malays live. As a teacher who come from the ancient manuscripts, they also communicate to the native indigenous communities (Malay) based on data obtained from the manuscript, and the results of their teaching activities led to some rules that are considered good and follow the laws applied in their rules in London.

While for certain countries, such as Malaysia, theybought some private collection of Minangkabau manuscript to collect it privately, to be used for specificinterests, such as the interpretation of our cultural identity to be applied to their culture. Therefore, the Riau government also seeks to take advantage of these ancient texts to examine how their culture in the past to be delivered to the next generation. Besides, Malays' scholars and intellectuals still use some texts as the foundation of their knowledge or their guidance. As for Riau, lately the content of the manuscript give some influence, such as in the religion, language, literature, law, history, customs, and education. Starting from this, the for government of Riau is using the script to build and reunite Malay language and culture in Southeast Asia, Riau County in particular and surrounding areas.

\section{Type of Manuscripts in Indonesia}

Ancient manuscrift in Indonesia is unknown by the people themselves, so that no one tends to care about the past cultural heritage, when actually ancient texts are containing useful and great wisdom for 
generations now. We described some of the contents of a collection of ancient manuscripts from the National Library 's various areas below:

1. History Manuscript of Pariaman (Latin alphabet, Malay, paper materials. The screenplay was written by the Baginda Said Zakaria in Pariaman. The manuscript consists of ten chapters, tell us about justice in Pariaman, livelihoods, ceremoniesofbirth,marriageceremonies, funeral rites, and ceremonies to build the house. Also there is a description about the mosques of Batu Pasar Pariaman, biography Sheikh Muhammad Jamil al- Khalidi (a Muslim religious leader in Pariama ) and the atmosphere during the month of Ramadan, including Shawwal 1st in Pariaman.

2. Originally Sambas' Kings Manuscript (Arabic and Latin, Malay, paper material). This is a prose text. It begins by the history of King Sapudak who ruled in the old town for generations. It was told, King of Brunei Fangah moved to Sambas. He had five son and each of them becomes king.

3. Maluku Chronic (Arabic, Malay, paper materials). This is a prose text. its begins with the miracle stories of the kings of Turkey, China, the Netherlands, and other countries, and then shows chronic of Moluccas.

4. Babad Lombok (Javanese script, Javanese language, materials paper. This script is macapat shaped, contains the history of Lombokbegins with the story of the prophets, untul the story about Karangasem Kingdom defeated Lombok

5. Hikayat Aceh (Arabic script, Arabic and Aceh, paper materials). This is a prose text, containing poems of praise addressed to the Prophet Muhammad. It also contains prayers.

6. Bomakawya script (Balinese script, Balinese, palm material). This is prose text and illustrated. Contains powerful war story between Krishna and Boma.

7. Sureq Baweng or Nuri's Letter (alphabet Bugis, Bugis language , material palm). This is prose text. Contains Sawerigading trip when looking for a good bride, equipped parrot stories containing advice, ordinances to propose a woman, and a number of moral teachings.

8. Parahyangan Story Script (Old Sundanese script, ancient Sundanese, material palm). This is a prose text, consisting of 45 lempir and each lempir consisting of four text lines. The story begins from the story of the sage teacher to all generations of kings in West Java.

9. Banten historical script (Arabic, Javanese, paper materials). This text is macapat shaped. The contents is about the family tree of the Prophet Muhammad and his descendants. It is also told Sunan Gunung Jati that inherited Sultans of Banten.

10. Laklak Script (script Batak, Batak, wood leather). This is a prose text, consisting of 38 pages. Tells stories about $\mathrm{Mr}$. Saribu, a King who has many children and grandchildren. Also described how to create a fortress strengths, good and bad forecasts, and offerings that need to be made every day.

11. Japar Sidik script (Arabic, Sundanese, paper materials). This is a prose text. Contains aphorisms based on the Islamic teachings and the minds of 
Sundanese people, such as the benefits of deliberation, a good day for hunting and traveling, trading, descent, and praiseworthy traits.

There was also a manuscript or codex that really give an effect for Indonesia, which is the Indonesian oldest Islamic Manuscript found in Terengganu, Malaysia. This manuscript named Batu Bersurat made in 1303 (14 AD). This article states about the spread and the Muslims at that time. This manuscript has been studied by history experts and Moslems archaeologists such as Prof. Naquib Alatas and others, all concluded that this manuscript is the oldest in Southeast Asia.

In 1310 (14 AD), it was also found on Islamic poetry in Malay written with Jawi letters in Minya ' Tujoh, Aceh. Therefore the experts agreed that the work of scholars who wrote the letter Jawi had developed in the 14th-century on Samudra Pasai Caliphate and other Islamic Caliphate in the Malaka Peninsula.

In younger age around 16-17 century in Aceh there were also quite a lot of author manuscripts for example, Hamzah Fanzuri, who was known as a famous Sufi at that time. Then there were the Sheikh Nuruddin ar- Raniri aka Sheikh Nuruddin Muhammad ibn ' Ali ibn Muhammad ibn Hamid Hasanji ar - Raniri al - Quraisyi. He was known as a scholar who also served as Qadi al - Malik al - Adil and Mufti Muaddam of the Sultanate of Aceh Muaddam $n$ the leadership of Sultan Iskandar Thani in the 16th century. One of his famous work entitled "Bustanul Salatin”. Sheikh Abdul Rauf al - Singkili are also defined as the Mufti and Qadi Malik Al-Adil in the Sultanate of Aceh during the four queens' period, also wrote many Islamic scripts.
Their works were not only developed in Aceh, butalso thrivethroughout Sumatra, the Malaka Peninsula to the South of Thailand. Their works also influenced the thinking and the beginning of Islamic civilization in Java, Sulawesi, Kalimantan, Nusa Tenggara, Maluku islands, Buton to Papua. So that in that area there are also some legacies of the work of scholars from Aceh. The next developments show emerge the Islamic work in other areas such as Sabilal Muhtadin Book of Sheikh al Banjari in Banjarmasin. There are also in Palembang. In Banten there was Shiykh al Banteni who also wrote many manuscripts. All of this manuscript is a reference of people and also the rulers at that time. Also found in other areas such manuskrip, Hikayat Raja-Raja Pasai, Hikayat Melayu , Hikayat Aceh, Hikayat Hasanuddin, Tripe Tana Jawi, Babad Cirebon, Banten Tripe, Carita Purwaka Caruban Nagari. In Southeast Nusa found a poem of Bima Kingdom, Bo'Sangaji Kai a note of Bima Kingdom. From Maluku, there is Hikayat Hitu. In Sulawesi there is Hikayat Goa, Hikayat Wajo and others.

The next is Pegon written manuscripts. commonly found in Central Java, East Java and Tatar Pasundan. The oldest works written Pegon for example, works of Sunan Bonang or Shaykh al- Barri, entitled Wukuf Sunan Bonang. The works written in the 16th century using the Java language mixed with Arabic. This manuscript is a translation and an interpretation of Ulumuddin Ihya byImam al - Ghazzali. This manuscript was found in Tuban, East Java. In this work, Sunan Bonang wrote, "The text was used by the Waliallah and the scholars, then I translate to the Mitran (friends) partners in spreading Islam in Java." This work is an example that in the 16th century, as growth era of the 
Islamic kingdom in Indonesia, is the same time developing the work of the scholars who played a major role in the spread of Islam in the archipelago.

\section{The Existence of Ancient Scripts or Manuscript Today}

Most of the manuscripts of ancient texts noted above, some of them are in Netherlands precisely at the University of Leiden. During the VOC and Dutch colonial, they collected, then steal and confiscated the classical Islamic manuscripts due to their interests. Some of the reasons were to perpetuate the colonialism and eliminate the traces of Islamic civilization from its original source in the Middle East. Muslims in the archipelago lost authentic sources of Islam development because the Muslims scholar was being seized; this is the reason why the colonialism lasted for hundreds of years.

The existence of ancient manuscript or the script in the Netherland is also stored in the National Library. The manuscript written by Jawi letters with the Malay language in the National Library of Jakarta only about 1,00o manuscripts, while others use Arabic or Arabic letters with smaller amounts, while in Netherlands, Islamic manuscripts from Indonesia written in Jawi reaches more than 5,000 manuscripts. Not to mention manuscripts written with the Pegon letter or Arabic, are much more.

Restoring the manuscript these days is not that easy, because its associated with hundreds of years old of physical form. So many parts are prone to damage when being touched, although these days there are international convention about heritage objects including the manuscript from a nation should be returned to the state is concerned, through conducting bilateral negotiations between the countries concerned. One of manuscripts that have been physically returned to Indonesia is Book of Negara Kertagama. This book was taken by the Dutch during the Lombok war. Another example is the most beautiful statue of Pradnya Paramitha from Singasari also been restored. Prince Diponegoro saddle also has been returned to our homeland by the Netherlands, including a case of gold and diamond ring from Lombok. If the restoration sare too risky due to physically damaged, the government can make efforts to make documentation such as digital microfilm.

The National Library has documented it in the microfilm record. During the tsunami in Aceh, so many original Aceh manuscripts were lost; therefore, today there are efforts to document the remaining manuscript using digital. Fortunately, in a boarding school in Metro Tanobe, NAD still saved over 2,000 classic texts from the $13^{\text {th }}-19$ th century the works of scholars from Aceh, and the Middle East. As the rescue process, it should be done by the local government. If the government unable to do it they could collaborate with some institutions for universities. In West Java, there are some attempts to do the catalog of classic texts from the Stone Age to the 19th century with Sundanese language or other languages that exist in various countries. The script is collected in catalogs than develop the microfilm so it can be learned again. Malaysia has also been made it, as well as the South Sulawesi. There must be rescue movement of ancient manuscripts, including nationally Islamic manuscripts.

\section{Utilization of Ancient Manuscripts for History Teaching and Writing}

In Indonesia, Teaching Indonesian history using scarce written source apparently are evolving especially by Indonesian teachers. Perhaps, it is caused by 
the inherent properties of the rare sources of teaching itself. Here, it is understandable that rare is not only the scarcity or difficult to obtain, but also unique, even exclusive. So, rare sources are an unique resources that the collection is difficult to obtain, in other words the rare resources inherent with scarcity. It also became clear that the range is limited because they aren't generally duplicated through a printing press or any other transmission medium.

It is not always but usually scarce resources which are talking about "old" time range so the intervals are too wide with the current teachers' lifetime. It could be identified that scarce resource is handwritten ancient texts or manuscripts. Many of the manuscripts were found and associated with the "classical period" of royal past. In the history science term, classification of scarce resources expanded to include chronicle, diaries, family document, memoirs, ancient manuscripts/official documents; are also unwritten sources like custom, folklore, even magical mishmash and myth.

We also cannot deny that teaching history that relies on scarce resources has brought new challenges for teachers. This paper tries to discuss scarce resources and/or resource scarcity as a historiographical aspect of the problem, particularly in the history teaching. The real question is what are the implications of scarce resources and/or scarcity of resources for the history teaching. Some of the work of teaching that mentioned in this paper merely as a supportive illustration to obtain a clearer description of the situation.

In its early development, historical research and teaching was virtually no scientific. The workings of the chroniclers are still limited in an effort to find the source of a history of ancient books or official papers and various reports. The documents read by the instructor and then quoted the parts that fit the theme of history to be written. There are no efforts to examine the historical sources; and the theme was usually limited to the biographies of important people, the greatness and falling of an empire, warfare and diplomacy between two kingdoms. In short, the general theme of the teaching of history in those days tended to the political and military aspects.

The changes in the ways of writing history started from the 17th century. Cultural atmosphere was characterized by the development of science and critical intellectual attitude emerged among writers of history. A French scholar, Jean Mabillon (1632-1707), regarded as the founder of the science of history called diplomatica, according to the title a book he wrote, De re Diplomatica (1681). Historians began to find different ways to examine documents or historical sources critically in order to produce the history teaching closer to the truth. And also Leopold von Ranke (17951815) a historian, also introduced the principle of critical selection of the historical data to establish the facts according to wie es eigentlich gewesen guidelines, as history actually happened (Barnes, 1963).

Today, generally it can be said that the development of the scientific method in history are growing. It is inseparable that history considered equal with the other sciences and become part of the college curriculum in many countries at least since the 19th century. Basically, the method of teaching history involves three important things. First, regarding ways to find the source of history, which is also commonly called heuristics. The recent history teacher might say "got benefit" by the establishment of institutions or government agencies and the private sector that serves as a place to 
store historical sources, such as national or regional libraries, national ancient script office. The second thing, after the source is found, is to examine the content of the source. How deep the content can be accepted as a source of information that can be trusted. It is able to extract information contained within its own expertise necessary resources, such as diplomatic as already mentioned before; paleography or ways to understand the ancient writings; chronology to match the dating then and now; lexicography or how to determine the meaning of terms of the past which are no longer used in the present; numismatic deals with how to determine the value of ancient currency; metrology or how to determine the size and weight that applies in a different times; toponimi or how to determine the names of places in the past, and so on (Barnes , 1963).

Third, relating with the writing of teaching results over those resources. Writing not only requires writing skills and mastery of the language, but also about understanding the terminology and specific theories that are relevant to the theme of the history studied. Generally, most of the historians stated that teaching and writing proficiency of learning outcomes are two things that cannot be separated.

From the brief description we can conclude that the first and the second aspect of the history method are closely related to the source. Conventionally, the source is a primary source especially written source. The fundamental view is that the primary source is part of the evidence of the past which became the source material, which became the foundation of what an event, incident, or any history symptoms can be reconstructed. As the time goes by, the primary sources getting further with teachers lifetime in the next day, so at some point will make the source contain become rare. As for the third aspect of the method, it is closely related to the development of theory and methodology that will not be discussed in this paper in particular.

It has been mentioned that the teaching of history that rely on scarce resources will bring a challenge for teachers. The problem is the fact that the physical condition of the old sources are fragile, so vulnerable to touch. Some attempts to transform it into another form (Celluloid, disks) can help to overcome the vulnerability but may also give new problems, such as dependence on reading devices, low technology, and so on. After that, the "real" difficulty appears related to the content or substance, alphabet and language that may not be understand by the teacher. It will become more complicated when scarce resources collection is stored in the "hidden" area or the location is far away from the teachers' place.

There is no doubt that inside the rare sources stored various information of the past. This means that scarce sources are not identical with the scarcity information of the content which is necessary in the history teaching. Early history teachers of Java, H.J. de Graaf, for example proves that by "only" studying traditional sources such as the Chronicle (of course with other sources), he managed to show the Java historical aspects in detail. As a Netherlands, he studied to a Java philologist RM Ngabehi Poerbatjaraka to "conquer" the difficulties in dealing with traditional sources, especially in terms of language. The result, among others, a complete history of Mataram - from emerging, developing, until the Kingdom collapse (see De regering van Panembahan Ingalaga Senapati (1954), De regering van 
Sultan Agung (1958) De regering van Sunan Mangku - Rat I Tegal - Wangi, 2 vols (1961, 1962), and other works.

The H.J. de Graaf's studied can be classified as a typical conventional history that determines the important events in elite level, while the broader social aspects do not get attention appropriately. However, the results of de Graaf's efforts throughout the decades it was seen as a solid foundation for the scientific study of the Java history in the 16-18 Century. According to a historian M.C. Ricklefs, who was a student of de Graaf, the importance of his teacher works lies in its pioneering work to compile a basic historical narratives as well as providing referral sources for those who would follow in his footsteps.

Later on, Ricklefs his own showed his reliability to continue de Graff efforts in compiling Java historical reconstruction based on scarce resources. Three of his masterpiece (see Jogjakarta under Sultan Mangkubumi 1749-92 (1974), War, Culture and Economy in Java 1677-1726 (1993), and The Seen and Unseen Worlds in Java 17261749 (1998) is a comprehensive trilogy to see historical development of Java, especially inside the palace, around period of 17th18th century. In these studies Ricklefs demonstrated his ability to process and analyze local resources intensively beside other types of sources. A little bit different from de Graaf who more emphasized at the elite level concentrate on the political and military aspects, then Ricklefs spread his attention on other aspects. in short, the Ricklefs' study described the dynamics of the Java community around the palace and its interaction with foreign powers (the West) that appear later. The interrelationship was including war or military and politics, economics, culture, literature, and religion. Aspects of religion (Islam) even indicated as
Javanese effort to find their identity in the middle of colonialism by VOC.

Ricklefs trail is followed by other foreign scholars who also use scarce resources intensively in their study, such as Peter Carey, Ann Kumar, Vincent Houben, and many more. Among others, the attention to the old history of outside Java is also shown by Denys Lombard Kerajaan Aceh Jaman Sultan Iskandar Muda 1607-1636 (1986), and Leonard Andaya (The Heritage of Arung Palaka (1981). Several examples of these studies are taken randomly and can be extended by relating with the results of a non-historical work of scholars such as philologist and literary -- for example Henri Chambert - Loir that compiled the Kerajaan Bima (2004). The information of scarce resources is also enriched by the services of ancient manuscripts cataloguists and ancient manuscripts collector.

As already mentioned before, from Indonesian scholars who learn about scarce resources as a historical study are still rare. Among the few that is Aminuddin Kasdi who wrote a dissertation of Perlawanan Penguasa Madura atas Hegemoni Jawa (published in 2003). A number of resources that are unpublished and published manuscripts are an important source in this study. Kasdi's studies concerning the end of Mataram (18th century), especially about the relationship between the center and regions is important because it has echoes of the nowadays problems, i.e. about regional autonomy. It shows that the past could find relevance to the present

\section{Innovation in History Learning and Teaching}

Learning is a very dominant part in realizing the quality process and graduator. Learning depends on the ability of teachers 
in presenting and implementing the learning process. If the learning is implemented properly and appropriately, it will contribute dominantly to students. Otherwise when learning are conducted either way will cause students' potential are difficult to develop. Therefore, teachers should know and understand the needs oflearninginnovations, particularly in the history teaching.

The word "innovation" is defined as the renewal and discovery. However, the word is also used to translate the word Invention and Discovery. These three words actually have different meanings, Discovery is the discovery of something that is actually found objects or things that already exist but have not been known. Invention is the finding of something completely new form of human creations. Found an object or thing that really has not existed before. While innovation is defined as an idea, items, events, methods perceived or observed by a person or group of people and something that is a new thing, both Invention and Discovery results. From that sense, it can be seen that learning innovation is something new and deliberately held to enhance the ability in order to achieve a learning goal. Learning innovation is held to help teachers and students in managing and organizing learning towards the achievement of learning objectives.

Learning is an activity that differentiates humans from other creatures. All human are learning throughout his life. Learning process is done with a series of formal, informal and non-formal educations. The learning process is conducted in order to change the inside of the learners, good knowledge, attitudes, and skills. The change is a result of the natural experience which are intentionally designed. Learning is not only conduct by the students, but also by every human being in order to solve the problem that so they can adjust to the environment. The characteristics of the study are the change in behavior as the result of individual interactions with the environment, and the behavior is permanent.

Thelearning process cannot be separated from the process and the outcomes. Learning refers to all activities designed to support the learning process that is seen by a change in individual behavior as learning objectives. This learning process must be intentionally well organized in order to foster a good learning process and achieve optimal learning outcomes. Therefore, the types of learning processes and learning outcomes become the focus of learning methods.

The history lesson is still considered second cluster subject until now, even any numbers of some subjects in school so that any teachers with any basic education and with consideration that history is the recite subject and considered easy subject, then any teacher can teach. It is an irony, when the government started to declare the professionalism in teaching with teacher certification, there are still commonly found in school where the history teacher who gave the material is not based on the history teaching as it should be. Teachers often showed his inability as a history teacher by creating innovative learning model, or using creative teaching methods.

History teacher inability to develop innovation in teaching history method can be caused by several factors, such as: 1 . The dense of subject matter making it possible to take a shortcut, means ignoring the affective and psychomotor aspects, 2. Teachers do not have the knowledge and skills to teach history that can attract students, and 3. Teachers tend to use one method in teaching the whole 
matter, regardless the characteristics of the material/topics presented. Besides, there are four components are interconnected, and the cause of the problem in the teaching of history, which are: 1 . History teachers who are generally poor of historical insight because there is a kind of intellectual laziness to explore the historical sources, either in the form of objects, documents and literature. A good history teachers are those who are able to stimulate the imagination and develop students in such a way, that the history stimulate curiosity; 2. History books and instructional media history is still limited, 3 . Learners who are not give many responses to learning history, and 4. Generally, teaching history is not challenge to students intellectually.

The settling of teaching history method is not only merely a trigger to interest learning, but also as one of the instruments that contribute to process students in order to get good results. The first step to revitalize the learning method is to try to understand how history subject should be. At least, there are five elements that should be implemented in history teaching: 1. Varied: any learning if it conducted monotonous will make students bored, and finally loss interest. This is happened in the history learning, since concentrated on the application of the lecture method, so the impression that emerges is the history subject is identical with the lecture method, even most history teachers assume that the historical material can be moved as a whole from head to head between teacher and students with the same learning methods, 2. Presentation from the facts to the analysis: the teaching of history in schools was emphasis on historical facts and memorizing facts such as actors, the events, and the scene. Ideally, learning the history is not just about transfer of knowledge but also the transfer of value, not only teaching students to be intelligent but also noble, because of it the aims of history teaching are to develop the science and also has didactic function, that is the purpose of history teaching is that the next generation that can take the values and lessons from the experience of his ancestors.

According to Mestika Zed, students are not enough crammed with cognitive busyness through memorization of facts that are already dead in the past, as many occur all this time (Kompas, August 13, 2005) . Soedjatmoko (1976:15) outlined that the history teaching by presenting the historical fact must be disposed, but also directed at understanding the analysis on historical fact This view is very important to implement in history teaching in order to avoid what is feared by Winamo Surachmad (19789), the students did not manage to achieve the ability level to see and to think historically but their history knowledge was stopped and bound by a set of data, facts, and the names of people. Therefore, the history teaching should not stop at the level of fact, but must come to the domain of analysis, 3. Open and dialogic: the history teaching practice is closed and monotone could bring the students in a rigid classroom atmosphere, raising the lack of enthusiasm. Therefore, teachers are required to design history learning become open and dialogical. The history teacher requires the openness and dialogue for not considering himself as the only true source in the classroom, because the teacher centered paradigm that tends to create a closed atmosphere in the classroom and cannot develop the students' creativity had to be abandoned and then switch to student centered learning, 4. Divergent: in line with the history teaching that emphasizes the analysis and dialogue, diverging principle 
application is very important in order to avoid the tendency of learning history that only convey historical fact, it means that teaching history requires problem solving by giving an opportunity to the students to analyze and make a lot of ideas, 5. Progressive: history teaching history be based on progressive principles. Nowadays, a new view of history education should be progressive and has firm view to the future. If history serves as an educational needs, then it should be able to provide smart solutions and relevant to the current social situation. The emphasis of this principle is the implementation of history subjects with tridimensional character. In this paper, the innovation development goals are to improve the history teaching learning quality through the optimization of the application of historiography in the learning process.

According to Paul L Dressel and Dora Marcus (1982), teaching does not merely know and distribute the knowledge, but rather an activity that is intended to inspire and help students to learn. The teacher is no longer the center of activity that determines each student's activity. The student who becomes the center, they are free to think and act (Hicks et.al, 1970). This does not mean that teachers lose their responsibility because the teacher acts as the teaching learning manager (Nasution, 1995), whereas according to the opinion of Eisner in (Craig, Mehrens, and Clarizio, 1975) that learning should be based on the creation of the environment that allows students to learn.

The quality of learning can be studied from several aspects, such as the aspects of: processes, teacher characteristics, and learning outcomes (Lucio and McNeil, 1969). All these aspects are intertwined to achieve the learning goals, whereas the learning goals (education) includes three aspects, which are: cognitive, affective, and psychomotor (Eggen , Kauchak, and Harder, 1979). The goal of cognitive effort associated with the development of students' intellectual, affective associated with social and emotional development, while psychomotor aspects relating to the development of student skills. It means that the learning could be qualified if it could develop these aspects on the student. This opinion is in accordance with the opinion of Dick and Reiser (1989) that the qualified learning is learning that allows students to get the skills, knowledge, and attitudes that have been set.

Kauchak and Eggen (1993) required a characteristic that must be held by qualified teachers, that is: having high expectations of their students, give examples of the desired behavior, teach with passion, and want to listen to their students; using the right language, the material presentation is logical and sustainable, use clear signals, proper attention, and harmony between the verbal and action are essential in effective communication; teachers teaching on time, preparing the material, and have a good habits.

In general, teachers are less aware of their role in fostering the history lessons; this is reflected by the frequent learning in schools under the spotlight of the public, because it turns out that the history learning organized in ways that are less adequate (Widja, 1989).

In history teaching (Banks, 1985), (Sylvester, 1973), and (Mays, 1974) expect the use of historical sources, including ancient manuscripts in teaching in schools. Students should try to find evidence of the past (historical sources), to process or give a criticism to the sources, to interpret, and then compile them into a historical story. 
Teachers are no longer the only information source in the classroom, but rather play a role in other dimensions, as a supervisor of student activity. The task of the student as a professional historian, though only at the introductory level, they can collect, process, interpret, and concludes resources in various ways. Ancient texts as sources or data can be used as a tool in analyzing the history facts depends on how teachers and students treat ancient texts as a source of analysis in the teaching of history. (Hamid Hasan, 1985). This Method or technique is then called the historiography or historical writing, then the utilization analysis for the study of ancient texts in the historical events conducted by the student with his teacher would give "integrity" in the history writing as a story and a facts. This way also expected can stimulate students to analyze historical events.

\section{Conclusion}

History is something that has value to the nation. Great nation is a nation that is able to appreciate the history because history is able to provide learning. History as a witness or a proof of journey of a nation is not only presenting memories, but also as a way of life for the present and the future. As a guideline, the history of a nation is the result of exhumation of the noble values that have been made by the nation. Therefore, it is common to be gained nations' moral values from writing the history and also national character at once.

According to W.J.S. Poerwadarminta (1984: 445), character is nature, behavior, psychological traits, morals or characters that distinguish one person to another. So, in short the nation's character is a natural trait possessed by a nation. History by Dudung Abdurahman (2007: 13) interpreted as the story of the events of the mankinds' past. From the definition, it is clearly stated that the history associated with everything that has happened in the past. While by the media, according to the Romiszowski and Basuki Wibawa (2001: 12) is defined as the messenger who comes from a source (which can be a person or thing) to the receiver of the message. Based on these opinions, the instructional media can be defined as a learning tool used to convey messages in learning. Instructional media is diverse, for example, movies, tapes, dvd's, and even the ancient scripts is included as a learning medium.

Public indifference to the nation history must be overcome remembering the importance to the survival of the nation itself. As mentioned by Wang Gungwu in T. Ibrahim Alfian (1985:3) that history has some uses, which are 1 . To preserve the identity of the group and strengthen the resilience of the group for survival, 2. To take the lessons and example from the past to provide more specific utility function for survival, 3. As a tools to understand the meaning of life and death.

Wang Gungwu explanation above gives us the understanding that history should not be forgotten. History that has passed not only related to the story, but the history of a nation must be accompanied by the presence of important documents, including ancient manuscripts. In Indonesian general Dictionary by W.J.S. Poerwadarminta, ancient manuscripts interpreted as deposits of important papers. Storage codex is not without purpose, but there is a purpose which is to be achieved primarily to the construction of the character of a nation. As we know that the Indonesian character today is very bad and it is not a secret anymore. The 
destruction of the characters can be proved by the rampant corruption case, officials can be bribe, a sense of unity is reduced, and the number of conflicts between ethnics lately. Character development is judged to be the main key to meet Indonesian life with better characters.

One such character development can be conduct by studying the ancient manuscripts that are part of Indonesian history. Relationship Context between the nation and state life with the presence of ancient manuscripts become increasingly important, because the scripts are strongly associated with the history of the nation. Furthermore it can be stated that the scripts are considered an accurate source of information that can be used as an authentic proof. The important means of ancient scripts concerning the potential content of stored information, such as, 1. Recognition of collective memory through the ancient scripts, 2. Ancient manuscripts as a tool to reveal behind the fact, and 3. Ancient scripts as a review of studies. From these explanations, we were able to clearly understand and know the importance of ancient manuscripts for life as part of a nation's history and an authentic proof. Scripts papers are not obsolete papers. However, behind it there is a very important lesson and valuable especially to build the nation's character.

As we know that a great nation is a nation that is able to appreciate its history. This award can be realized by studying one part of the history, the ancient manuscripts. In the formation of character, the ancient manuscripts have a big contribution, for example, by studying the ancient texts, the public will know theorigin of their nation from the story, the story and the facts submitted from the manuscript is necessary to establish the character of the nation today.
Considering the importance of history for life, then as a nation we should learn and understand it. History as a teacher will provide valuable lessons for the survival of this nation. Learning history can be started from studying the ancient texts as ancient texts are a major part of the Indonesian history. Studying the ancient texts is an effort to build the character of Indonesia which is now starting to decrease.

Through the medium of ancient manuscripts the Indonesian people are expected to learn from life values contained in the manuscript. The script usually use languageorliteracywhichsignifieshospitality, human values, which is a symbol of selfexpression, spiritual, behavioral, ethnicity, culture and the arts as well as indicating the time of manufacture by the author, includes broader life such as philosophy, religion, faith, business, domestics, expertise, and other skills.

Many of manuscripts which had a copy of which is vulnerable because of their age, a copy is also one way to preserve ancient manuscripts. In the present, we can see ancient scripts in the national library or local library, even now many collectors who have deliberately kept as collectibles only. The existence of manuscripts scattered throughout the world is increasing the wealth of our manuscript, but only a few that are still intact (good condition) and many which have been copying. Recopying is one way to preserve the existence of rare manuscripts. So many texts which the existence are not konown make it unmaintained even scattered.

The function of the script for today's society in general is just as rare goods stored as antiques. Most of the people do not realize the meaning contained in the text. According 
to researcher the existence of ancient texts can be used for the history teaching, particularly as an analysis source of historical materials studied together between teachers and students in the classroom. Ancient scripts can be used as study materials and reference for the development of the science of history.

\section{REFERENCES}

Abdurahman, D. (2007). Metodologi Penelitian Sejarah. Jogjakarta: ArRuzz Media.

Alfian, T.I, dkk. (1984). Bunga Rampai Metode Penelitian Sejarah. Yogyakarta: LERES IAIN Sunan Kalijaga.

Bank, James A. (1985). Teaching Strategies for the Social Studies. New York: Longman, Inc.

Craig, Robert C., Mehrens, William A., dan Clarizio, Harvey F. (1975). Contemporary Educational Psychology. New York: John Wiley and Sons, Inc.

Dick, Walter, dan Reiser, Robert A. (1989). Planning Effective Instruction. Boston: Allyn and Bacon. Kuntowijoyo. (1994). Metodologi Sejarah. Yogyakarta: Pt. Tiara Wacana.

Gottschalk, L. (1981). Understanding History: A Primary of Historical Method (terj.) Nugroho Notosusanto, Jakarta: Uneversitas Indonesia Press.
Hamid Hasan. (1985). Pengajaran sejarah antara Harapan dan Kenyataan. Makalah. Seminar Sejarah Nasional di Yogyakarta.

Hopkins, David. (1993). A Teacher's Guide to Classroom Research. Bristol: Open University Press.

Kasihani, K. (2001). Penelitian Tindakan Kelas. Malang: Universitas Negeri Malang.

Kauchak, D. P. dan Eggen, Paul D.(1993). Learning and Teaching, ResearchBased Methods. Boston: Allyn and Bacon.

Nasution, S. (1995). Didaktik Asas-asas Mengajar. Jakarta: Bumi Aksara.

Poerwadarminta, W.J.S. (1984). Kamus Umum Bahasa Indonesia. Jakarta: Balai Pustaka.

Sylvester, D. (1973). Teaching History. London: Grom Helm, Ltd.

Tilaar, H.A.R. 1993. "Dirregulasi Pendidikan Nasional dalam Rangka Implementasi UU No 2 Tahun 1989 pada Repelita VI'. Buletin LPMP, No. 4. Jakarta: LPMP - IKIP Jakarta.

Widya, I Gde. (1989). Pengantar Ilmu Sejarah dalam Perspektif Pendidikan. Semarang: Satya Wacana. 